\title{
Microclimate changes, photomorphogenesis and water consumption of Moringa oleifera cuttings under different light spectrums and exogenous phytohormone concentrations
}

\author{
Alexandre Eugênio da Silva ${ }^{1}$, Rener Luciano de Souza Ferraz ${ }^{1 *}$, João Paulo da Silva ${ }^{1}$, Patrícia da Silva \\ Costa ${ }^{2}$, Pedro Roberto Almeida Viégas ${ }^{3}$, José Félix de Brito Neto ${ }^{1}$, Alberto Soares de Melo ${ }^{4,6}$, Kaline de \\ Souza Meira ${ }^{1}$, Cláudio Silva Soares ${ }^{1}$, Ivomberg Dourado Magalhães ${ }^{5}$, Aldair de Souza Medeiros ${ }^{5}$
}

\author{
${ }^{1}$ State University of Paraíba, Center for Agrarian and Environmental Sciences, Lagoa Seca, 58117-000, Paraíba, Brazil \\ ${ }^{2}$ Federal University of Campina Grande, Academic Unit of Agricultural Engineering, Campina Grande, 58109-970, \\ Paraíba, Brazil \\ ${ }^{3}$ Federal University of Sergipe, Department of Agronomic Engineering, São Cristóvão, 49100-000, Sergipe, Brazil \\ ${ }^{4}$ State University of Paraíba, Coordination of the Post-Graduate Program in Agricultural Sciences, Campina Grande, \\ 58429-570, Paraíba, Brazil \\ ${ }^{5}$ Federal University of Alagoas, Department of Plant Production, Maceió, 57072-900, Alagoas, Brazil \\ ${ }^{6}$ Fellow of CNPq Research Productivity, level 2, Brazil
}

\section{*Corresponding author: ferragroestat@gmail.com}

Abstract

Moringa oleifera is one of the most important plants in the world due to its multiple uses as well tolerance to abiotic stress. However, it may presents low quality seedlings in protected environment under thermal and luminous stresses. The current study aimed to evaluate environmental microclimate changes; photomorphogenesis and water use of $M$. oleifera cuttings under light spectral and phytohormones variations, as well as to identify the most important variables to explain those effects. A completely randomized experimental design was used in a $4 \times 4$ factorial design with four replications. Four luminosity conditions, white (a transparent plastic layer), blue (two layers of blue cellophane paper), red (two layers of red cellophane paper), and extreme red lights (one layer of red cellophane and one of alternating blue cellophane) and four phytohormones concentrations $(0,25,50$, and $100 \%)$ were applied. M. oleifera semi-woody cuttings were collected from 7 am to 9 am from the $M$. oleifera mother plants, grown on a rural property located in the city of Lagoa Seca, Paraiba, Brazil, with the following characteristics: $15 \mathrm{~cm}$ in length, 4 to $5 \mathrm{~mm}$ in diameter, and 2 or 3 buds. Throughout the experimental period, environments were monitored to determine illuminance, average air temperature, relative humidity, soil average temperature, and evapotranspirated water consumption by cuttings. The numbers of shoots were recorded weekly. The number of surviving roots and shoots were measured 60 days after $M$. oleifera cuttings planting. Illuminance was reduced in environments under blue, red, and extreme red lights, respectively. The air temperature was reduced under blue light, while red and extreme red lights induced the increase on air temperature and relative humidity, soil temperature, and therefore, water consumption of cuttings. Protected environments when irradiated with blue light and application of phytohormones at concentrations of 25 and $50 \%$ enabled the shootings and survival of cuttings, although no root formation was observed after 60 days from planting. All variables were considered important to explain the effects.

Keywords: water demand; plant hormones; Moringaceae; light quality; temperature; relative humidity.

Abbreviations: AAT_average air temperature; AMC_analysis of main components; AST_average soil temperature; BLH_blue light; oC_degree Celsius; CWC_cuttings water consumption; DAP_days after planting; DWV_drained water volume; EPET_exogenous phytohormones extracted from "Tiririca" tubers (Cyperus rotundus); ILU_illuminance; IWV_initial water volume; Ix_lux; MCs_major components; MDS_mass of dry substrate; $\mathrm{mL}$ milliliter; mm_millimeter; NOR_root number; NOS_number of shoots; NSS_number of surviving shoots; $r_{-}$correlation coefficient; RAH_relative air humidity; RLH_red light; SME_substrate mass after evapotranspiration; SMF_soil mass at field capacity; v/m_volume per mass; VWR_volume of water required; WLH_white light; WSF_water volume in the substrate at field capacity; XRL_extreme red light; \%_percentage; \pm ;more or less; $\Sigma_{-}$sum; $\overline{\mathrm{X}} \_$average; $\sigma^{2}$ _variation; $\lambda \_$eigenvalues.

\section{Introduction}

In the last decades, world population, expansion of agricultural area, energy, and industrial sectors have been increasing significantly. Therefore, demand of natural resources, mainly water resources, has been rising as well. As a result, water scarcity has become a significant problem each year in a vast number of countries in the world (Zhang et al., 2019a). This scenario is remarkable in arid and semiarid regions, in which there is a poor spatial and temporal rainfall distribution and this behavior causes long periods of drought and extreme rainfalls, which directly affects water availability and supply for human consumption, development of agriculture, and the provision of ecosystem services (Mutti et al., 2019). 
It is broadly known that foods production and consumption are related to the main environmental impacts such as greenhouse gas emissions (GGE), water pollution, and loss of biodiversity, which in the future, will be aggravated by increasing global demand for natural resources for food production and security (Azzurra et al., 2019). In this case, agricultural expansion requires plants with high added value with both food and energy potential such as Moringa oleifera Lamark., because agricultural activities are closely linked to the consumption of these natural resources, particularly, energy and water (Páramo-Calderón et al., 2019; Valenga et al., 2019).

Cultivation of $M$. oleifera looks extremely relevant, once this tree-structure plant is fast growing and belongs to Moringaceae family also known as tree of life due to its multiple applicability such as water purification, biopesticide, cosmetic, pharmaceutical, and medicinal properties. All these uses are assigned to the wide range of phytochemicals produced by it, becoming a very important plant for developing countries (Aekthammarat et al., 2019; Virk et al., 2019).

M. oleifera leaves and pods are important sources for human and animal food industries, mainly due to its high nutritional value, besides being able to provide food security and contribute to more sustainable agricultural practices and the development of rural areas, especially in the semiarid region of Northeast of Brazil (Domenico et al., 2019; Zhang et al., 2019b).

The literature on the implications of light spectral variation and exogenous phytohormones in the budding of $M$. oleifera cuttings is fundamental, demanding the necessity investigations to understand these processes, because it is already known that variations in the light spectrum may influence plants (Long et al., 2018). Indeed, light spectrum is important to plant due to the fact that vegetal have specialized photoreceptors on perception of environmental light signal and transduction of signals for development of vital processes (Fukuda, 2019; Kong et al., 2019).

In relation to the luminosity condition, it is observed that light perception by these photoreceptors systems triggers a series of responses to plant acclimatization to shading by adjustment of its morphology, biochemistry and physiology. These acclimatization responses tend to improve the uptake and use of light under the shade, minimizing negative effects on plant growth (González et al., 2019). This information are essentials for providing theoretical basis for research about light influence on $M$. oleifera cuttings photomorphogenesis especially in semiarid regions with high light availability.

Light may modify phytohormones balance on vegetables influencing germination, growth, and development (Yang et al., 2018). In this context, acquisition of exogenous phytohormones is a promising strategy and it may be obtained from aqueous extract from tiririca tubers (Cyperus rotundus L.) because of expressive amount of indoleacetic acid (Cavalcante et al., 2018). It is worth pointing out that phytohormones are important to mitigate luminous, thermal, and water abiotic stress that occur in a protected environment at certain periods of the year (Aguilar-Camacho et al., 2019; Podlešáková et al., 2019).

The objective of this research was to evaluate environmental microclimatic changes, photomorphogenesis, and water consumption by $M$. oleifera cuttings under light spectrum variations and exogenous phytohormones concentrations, as well as to identify the most important variables to explain the interaction effects among the factors under study.
Results and Discussion

\section{Environmental microclimate changes}

Based on analysis of variance, we found that light conditions lead to significant differences to all assessed variables, while phytohormones had significant influence on average air temperature and water consumption. A significant interaction was observed between light conditions and phytohormones concentrations on water consumption by $M$. oleifera cuttings (Table 1 ).

All light conditions promoted different illuminance on protected environment, as descending order of white light illuminance $(1107.25 \mathrm{Ix})$ followed by red light (676.42 Ix), extreme red $(572.25 \mathrm{~lx})$, and blue light (417.17 Ix) (Fig 1A). The mean air temperature remained similar among light conditions with white, red, and extreme red lights, with averages of $37.77,37.58$, and $38.16^{\circ} \mathrm{C}$ respectively, whereas under blue light, air average temperature was reduced to $34.75^{\circ} \mathrm{C}$ (Fig 1B).

It is possible that the lowest illuminance observed on blue light environment has induced a better cuttings acclimatization on shoots and their subsequent survival, because blue light triggers photomorphogenic modifications to adapt plants to lower illuminance environment, especially the lower production of 'a' chlorophyll and an increase in ' $b$ ' chlorophyll contents, inducing weaker relation between these two photosynthetic pigments and consequently better interception of photosynthetically active radiation in low luminosity environments, as the one that occurred under blue light (Ma et al., 2014).

The results and relevance of this current investigation may be supported by Purquerio and Tivelli (2006), as these researchers reported that cultivation in a protected environment is a specialized agricultural technology, which enables edaphoclimatic conditions control such as: temperature, air humidity, radiation, soil, air, and atmospheric composition. These information are important to improve technological options for seedlings production and protected environment cultivation, especially using colored plastic covers (Gao et al., 2019).

However, the choice and management of the protected environment must be adequate, because the higher temperatures in undesirable protected environment management may cause increase in infrared and caloric radiation. This generates internal temperature increase in the environment and this may induce thermal stress in the vegetables, mostly by metabolism acceleration with enhance on respiratory process and protein denaturation, which implies reducing the photosynthetic process (Santos et al., 2010).

The environment under extreme red light had higher relative humidity $(32.75 \%)$, while environments under blue and red lights presented relative humidity of 28.17 and 28\%, respectively. The lower relative humidity (21.92\%) was observed at white light environment (Fig 2A). Soil temperature was higher at red and extreme red lights environments, 41.38 and $42.35^{\circ} \mathrm{C}$ on average, respectively. These ones differed from the environments under white and blue lights where soil temperatures of 36.55 and $35.63^{\circ} \mathrm{C}$ were recorded, respectively (Fig $2 \mathrm{~B}$ ). The greatest hot air mass accumulation inside protected environments under extreme red light may be related to the increase of soil temperature, which induced a higher soil water evaporation into atmosphere according to Santos et al. (2010). The 
wavelengths at infrared region results on increase of temperature, which in fact, may have occurred in the polyethylene bags to induce evaporation raise.

For blue light, the reduction of the direct incidence of sunlight is beneficial to the species that require less radiant energy flow, especially by temperature reduction. In fact, this lower incidence of solar energy can contribute to decrease extreme effects of radiation, mainly photorespiration, and provide better environmental conditions, which may have favored cuttings shooting and survival (Maciel et al., 2007).

In relation to the lower relative humidity and soil temperature observed in the environment under white light, we should emphasize that this environment was not completely closed and covered with black plastic at the bottom to prevent the entry of white light. Therefore, the occurrence of winds may have transferred the mass of hot air out of the greenhouse, as well as cooling the soil ground. This is congruent with Lemos Filho et al. (2010) that reported influence on reference evapotranspiration from the spatial analysis of the meteorological elements. They verified that regions where occurred high advection, mainly when a wet area is surrounded by a dry area, wind speed and relative humidity gain importance in the process of cooling the soil surface.

\section{Cuttings water consumption}

From the unfolding luminosity conditions within phytohormones concentrations, it was possible to verify that, without phytohormones application ( $0 \%$ of EPET), cuttings grown under extreme red light had the highest water consumption $(988.33 \mathrm{~mL})$, while under white and red lights the same cuttings consumed 618.33 and $623.33 \mathrm{~mL}$ respectively. An intermediary water consume $(776.33 \mathrm{~mL})$ was observed under blue light. When $50 \%$ of EPET concentration was applied, the highest water use $(1,026.33$ $\mathrm{mL}$ ) took place under red light, which differed from the 609 and $574 \mathrm{~mL}$ consumed by the cuttings grown under white and blue light, respectively (Fig $3 \mathrm{~A}$ ).

Application of different phytohormones concentrations among light conditions showed that cuttings grown under light had $756.56 \mathrm{~mL}$ of water consumption without EPET application (0\%). However, we registered a decrease of $533.28 \mathrm{~mL}$ under $46.79 \%$ of EPET application followed by the increase to $822.11 \mathrm{~mL}$ with $100 \%$ of EPET application (Fig 3B).

Under red light, cuttings grown without EPET application showed a $582.66 \mathrm{~mL}$ of water consumption. However, cuttings showed an increase of $979.49 \mathrm{~mL}$ with the addition of $70.92 \%$ of EPET, followed by reduction to $912.76 \mathrm{~mL}$ with addition of $100 \%$ EPET (Fig 3C). When cuttings were grown under extreme red light, the increase in EPET concentrations significantly reduced water consumption and evapotranspiration, showing a decrease from $923.6 \mathrm{~mL}$ without EPET application (0\%) to $715.94 \mathrm{~mL}$ with $100 \%$ EPET (Fig 3D).

Higher evapotranspiration and water consumption was observed in the red and extreme red lights environment, associated to the cuttings shoots as well as the consequent elevation of their transpiratory activity, which is due to the fact that these environments combine higher temperatures with the more effective wavelengths for light capture by chlorophylls and carbohydrates synthesis. Indeed, evapotranspiration increases are due to the changes in environments because this process simultaneously involves evaporation and transpiration, which are controlled by the water supply to the plants and by the availability of energy resulting from interaction with the meteorological variables that drive the atmospheric demand (Pivetta et al., 2010).

The quantification of evapotranspiration is crucial for understanding the water balance and for the efficient planning of the use of water resources, especially for the use of irrigation (Parajuli et al., 2019). It is important to point out that several factors may interfere with plant evapotranspiration. Among which, we may highlight stomatal opening, the reflectance, aerodynamic roughness, extent of the area covered by the plant, season of the year, energy availability, atmospheric demand and soil water supply to plants (Fernandes et al., 2011). In this context, colored covers should be used in an appropriate way so as not to increase water consumption and cause water deficit in plants.

\section{Shooting and survival of cuttings}

The weekly observations showed that 16 days after cutting planting (DAP), one shoot was counted on the cuttings under blue light, both in the absence of phytohormone (EPET) and 25\% EPET application, while two shoots were recorded under 50 and $100 \%$ EPET applications. Application of $100 \%$ EPET under red light induced two shoots, while under extreme red light just one shoot was recorded (Fig 4A). Under blue light, cuttings grown for 60 days (DAP) showed one surviving shoot under $25 \%$ of EPET and two surviving shoots in cuttings treated with $50 \%$ of EPET, while under other lights and FEAT combinations all shoots died (Fig 4B). A partial view of the shoots may be seen in Figures $4 C$ and $D$.

The greater number of shoots under blue light, besides those verified under red and red extreme lights should be attributed to the fact that $M$. oleifera has specific photoreceptors for the perception of stimulus from environment light in order to modify phytohormones balance and influence lateral buds cell differentiation. Apparently, supplementation with blue light has promoted shoot elongation once this process is driven by the interaction between red and blue light, contained in white light. Therefore, the blue light is responsible for the release of lateral buds and shoots growth (Jeong et al., 2014).

Red and blue lights detection on higher plants is carried out by different light photoreceptors (Oka and Yamamoto, 2019) in a way that these lights induce different effects on plant development and biosynthesis of cellular components. This fact might explain both the death and the survival of $M$. oleifera shoots under blue light, mainly because the red light is important for development of the photosynthetic apparatus, floral induction, shooting, starch accumulation in plants, which may lead to death of shoots by high metabolic activity without the presence of roots to supply water and nutrients. However, under blue light plant regulation such as opening of stomata, leaves expansion, and biomass production can occurs, contributing to the survival of the shoots under blue light illuminance (Xu et al., 2012; Lin et al., 2013).

It is possible that shoots survival under blue light is linked to the combination with energetic lights. For instance, ultraviolet and blue lights, and high temperatures are effective in raising the levels of phenolic compounds and ascorbic acid, as well as increasing the activity of enzymes involved in the removal of reactive oxygen species. 
Table 1. Summary of variance analyze for microclimatic variables and water consumption by $M$. oleifera cuttings under light spectrum and phytohormones variations.

\begin{tabular}{|c|c|c|c|c|c|c|}
\hline \multirow{2}{*}{ Sources of Variation } & \multirow{2}{*}{ DF } & \multicolumn{5}{|c|}{ Average of squares } \\
\hline & & ILU & AAT & RAH & AST & CWC \\
\hline Light (L) & 3 & $1050169.46^{*}$ & $29.26^{* * 1}$ & $237.02^{* * 4}$ & $141.01^{* *}$ & $123441.74^{*}$ \\
\hline Phytohormones (P) & (3) & $2280.18^{\mathrm{ns}}$ & $2.14^{*}$ & $11.13^{\mathrm{ns}}$ & $1.22^{\mathrm{ns}}$ & $56221.52^{*}$ \\
\hline Linear Regression & 1 & $4968.04^{\text {ns }}$ & $1.67^{\text {ns }}$ & $13.39^{\mathrm{ns}}$ & $0.16^{\text {ns }}$ & $57927.51^{\text {ns }}$ \\
\hline Quadratic Regression & 1 & $1473.21^{\text {ns }}$ & $0.79^{\mathrm{ns}}$ & $19.94^{\mathrm{ns}}$ & $1.24^{\mathrm{ns}}$ & $44790.91^{\mathrm{ns}}$ \\
\hline Regression Deviation & 1 & $399.30^{\text {ns }}$ & $3.97^{*}$ & $0.07^{\text {ns }}$ & $2.28^{\text {ns }}$ & $65946.13^{\text {ns }}$ \\
\hline Interaction $\mathrm{L} \times \mathrm{F}$ & 9 & $1859.09^{\text {ns }}$ & $0.48^{\mathrm{ns}}$ & $5.78^{\mathrm{ns}}$ & $0.29^{\mathrm{ns}}$ & $56571.02^{* *}$ \\
\hline Residue & 32 & 2828.52 & 0.54 & 5.29 & 0.91 & 17690.93 \\
\hline CV (\%) & & 7.67 & 2.00 & 8.30 & 2.46 & 18.05 \\
\hline
\end{tabular}
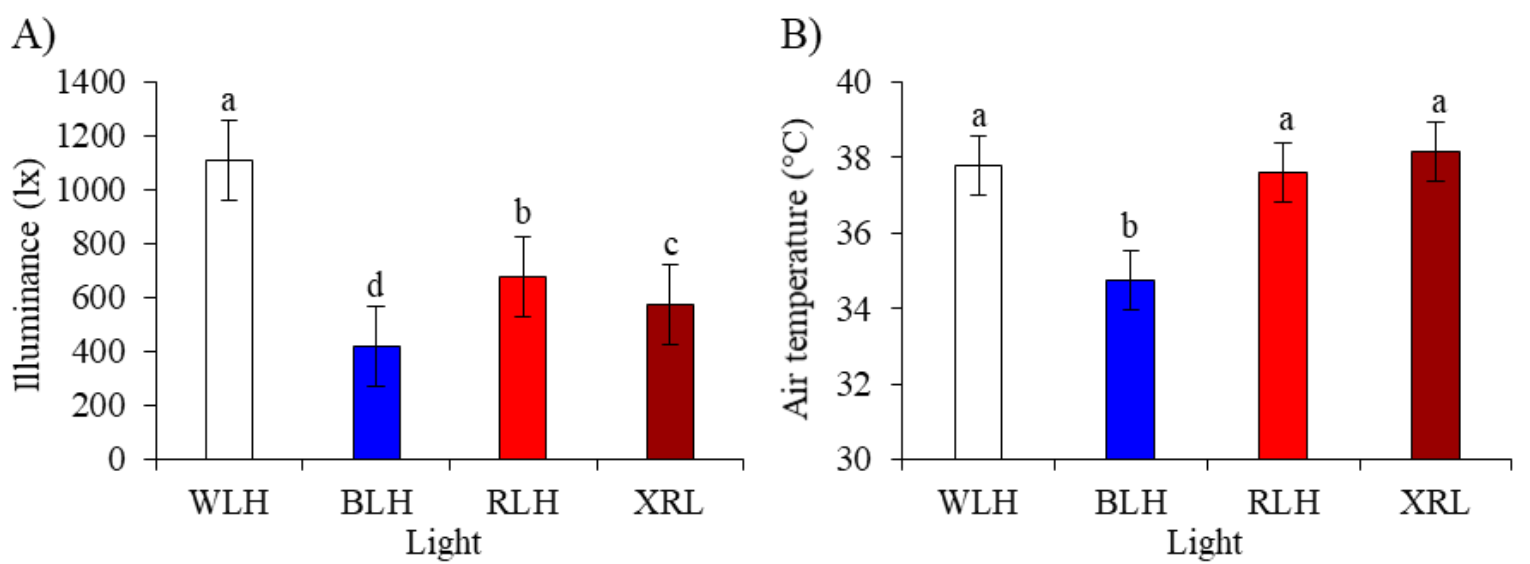

Fig 1. Illuminance $(A)$ and average air temperature $(B)$ in protected environments under light conditions with white light (WLH), blue (BLH), red (RLH), and extreme red (XRL).

A)

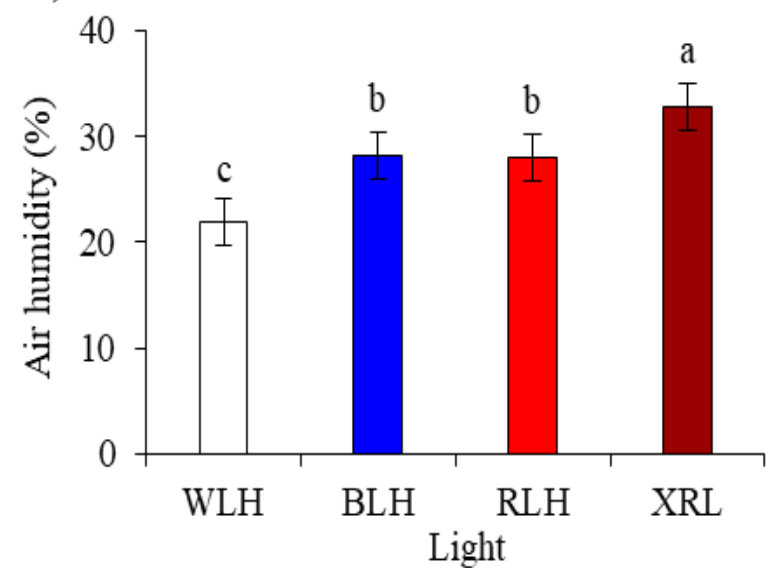

B)

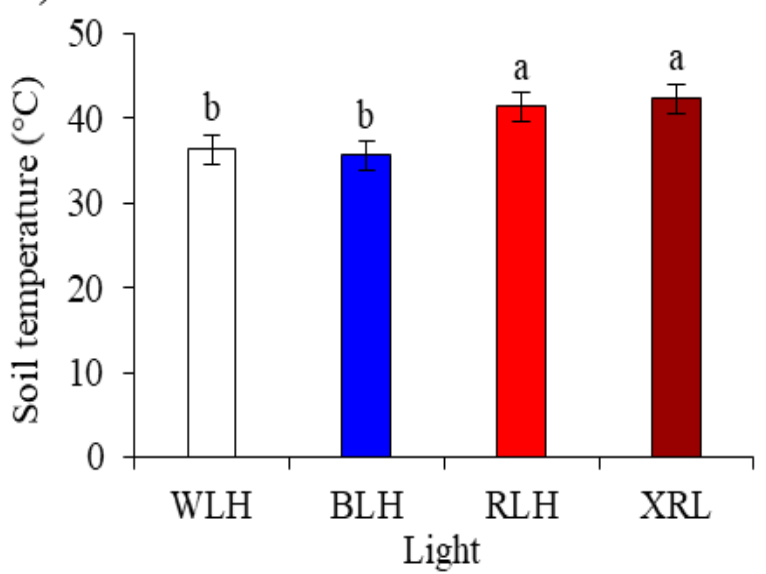

Fig 2. Air humidity (A) and average soil temperature (B) in protected environments under light conditions with white light (WLH), blue (BLH), red (RLH), and extreme red (XRL).

Table 2. Summary of the analysis of microclimatic changes main components, photomorphogenesis, and water consumption by $M$. oleifera cuttings under light spectrum variations and phytonutrient concentrations.

\begin{tabular}{|c|c|c|c|c|c|c|c|c|c|}
\hline \multirow{2}{*}{$\mathrm{MCs}$} & \multirow{2}{*}{$\Lambda$} & \multirow{2}{*}{$\sigma^{2}$} & \multicolumn{7}{|c|}{ Correlation coefficients ( $r$ ) among variables and MCs } \\
\hline & & & CWC & AAT & $\mathrm{RAH}$ & AST & ILU & NOS & NSS \\
\hline $\mathrm{MC}_{1}$ & 2.87 & 40.98 & -0.44 & -0.93 & -0.15 & -0.76 & -0.43 & 0.73 & 0.72 \\
\hline $\mathrm{MC}_{2}$ & 2.45 & 35.03 & 0.62 & -0.19 & 0.91 & 0.56 & -0.87 & 0.37 & 0.02 \\
\hline
\end{tabular}

relative humidity; AST: average soil temperature; ILU: illuminance; NOS: number of shoots; and NSS: number of surviving shoots. 

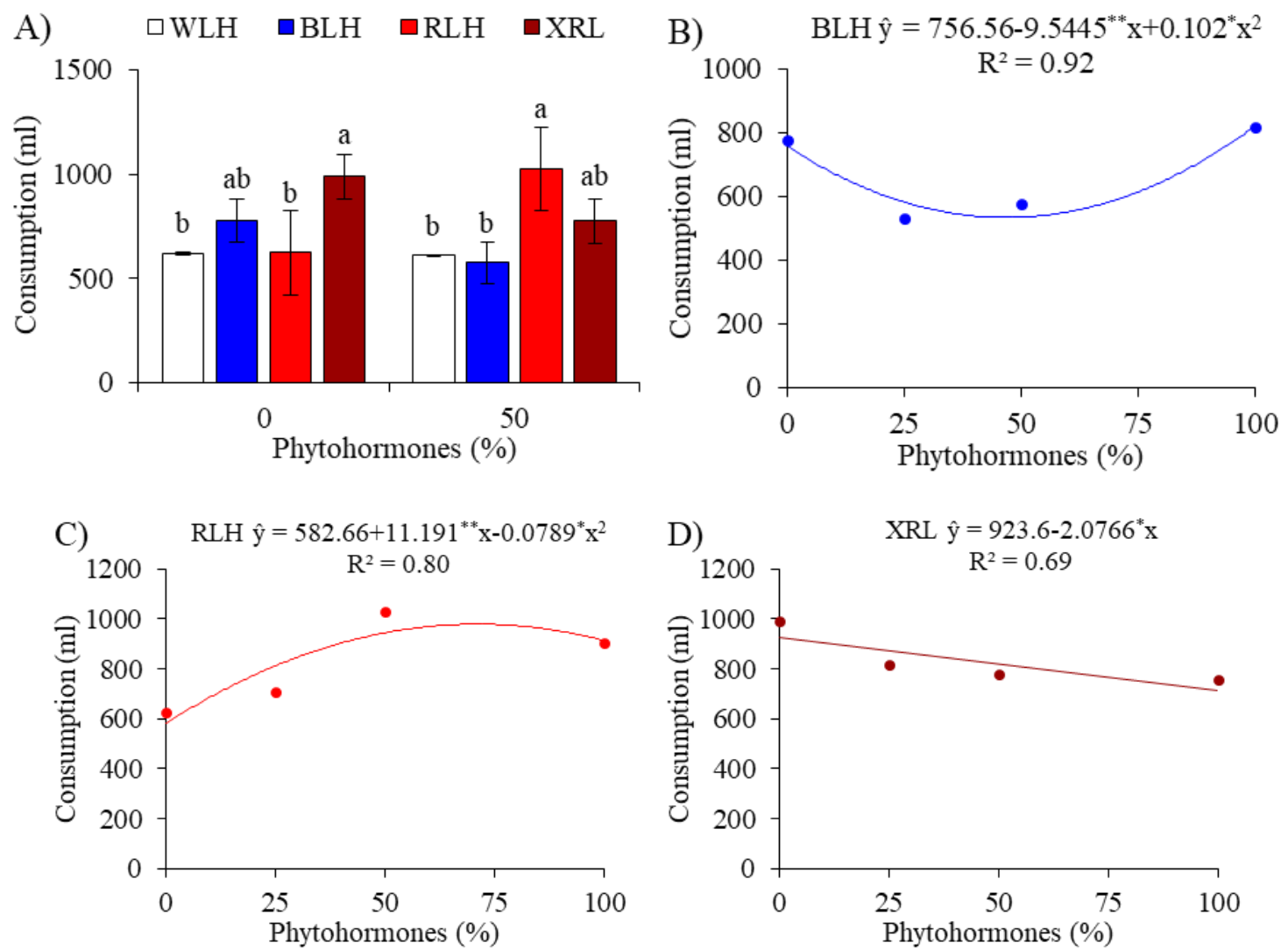

Fig 3. Evapotranspirated water consumption by $M$. oleifera cuttings according to the unfolding light treatments within phytohormones (A) and phytohormones within blue (B), red (C) and extreme red lights(D).
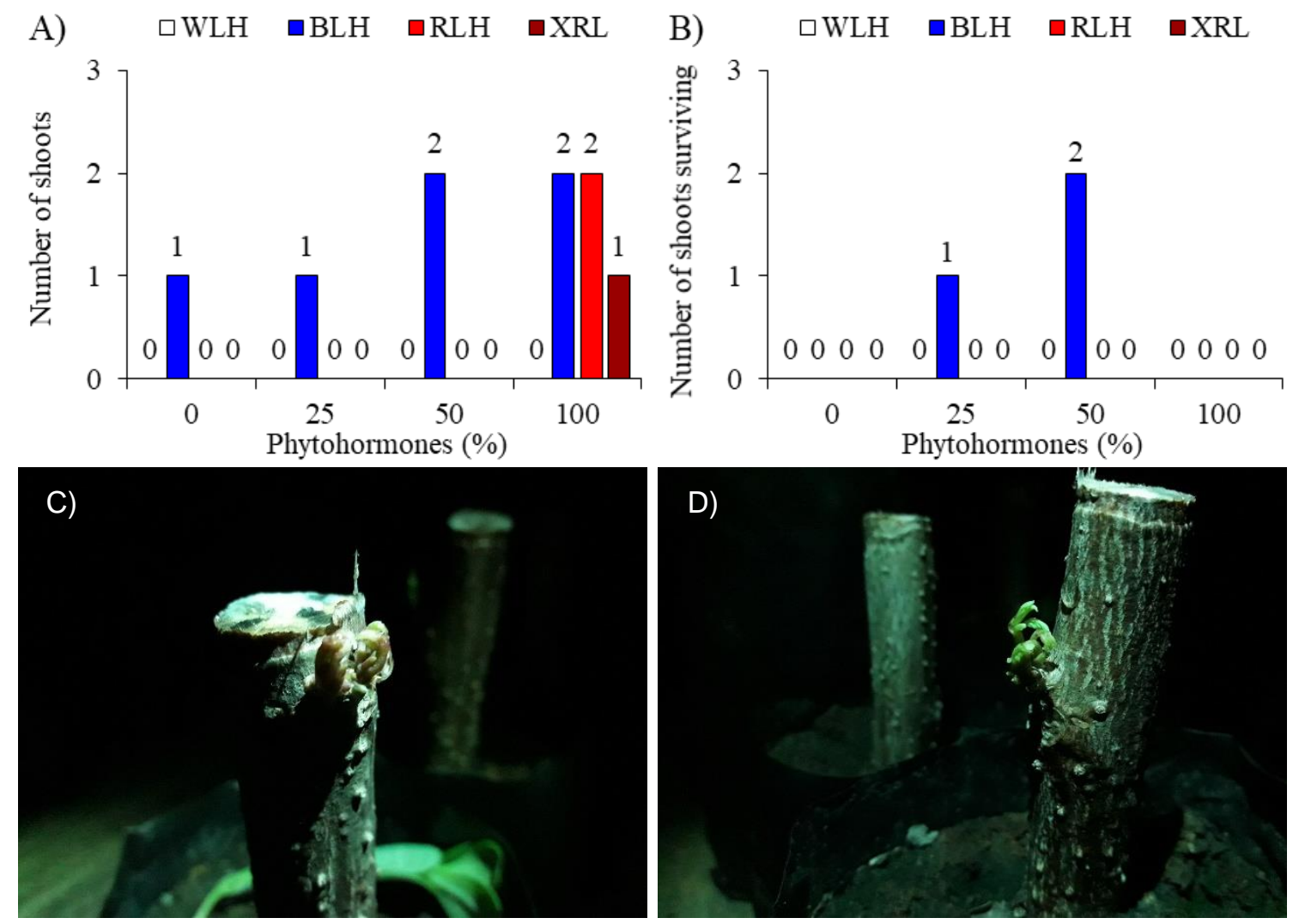

Fig 4. Number of shoots at 16 days after planting (A), number of shoots surviving at 60 days (B), and night shoots images, using a green light filter ( $C$ and $\mathrm{D})$, on $M$. oleifera cuttings under light and phytohormones. 

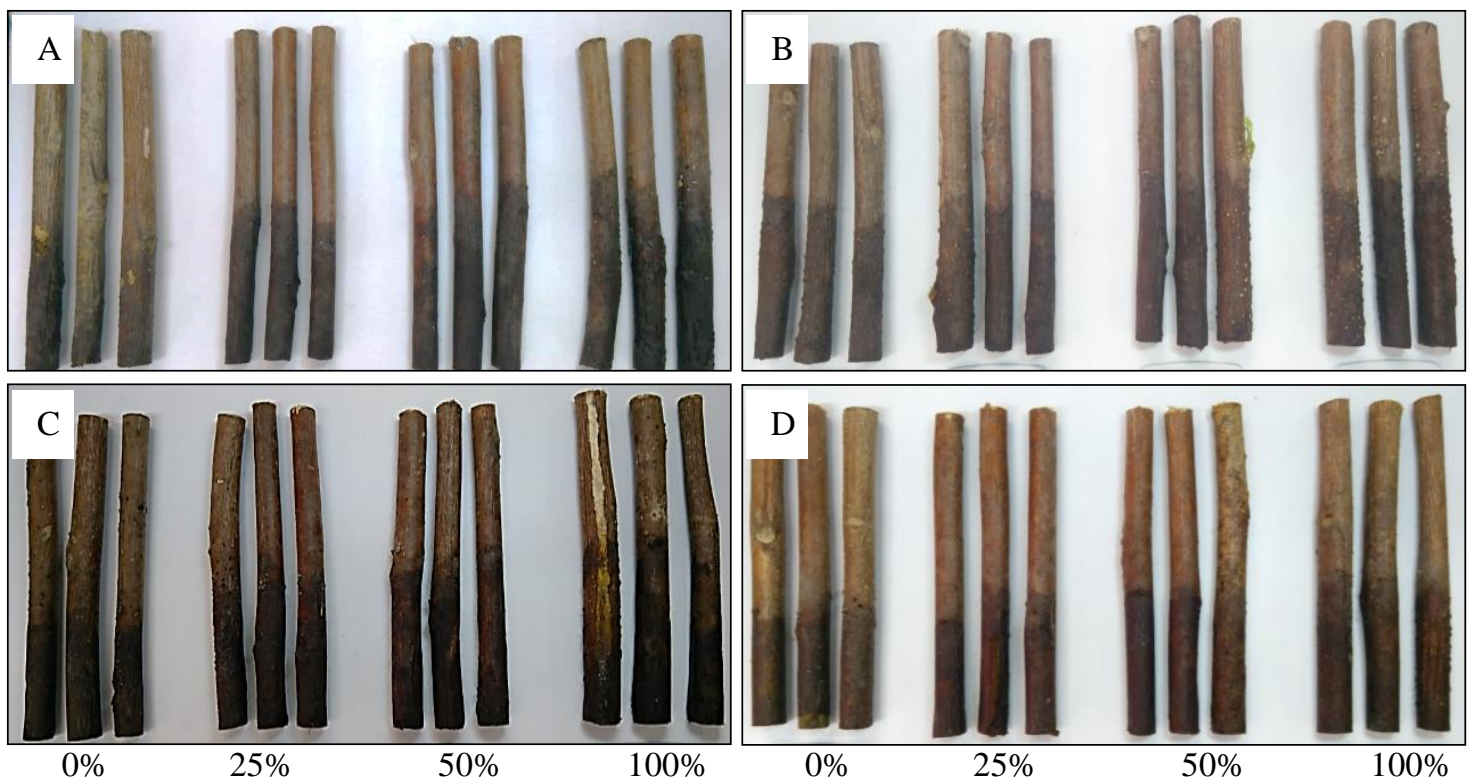

Fig 5. M. oleifera cuttings 60 days after planting in light conditions under white (A), blue (B), red (C) and extreme red lights (D).
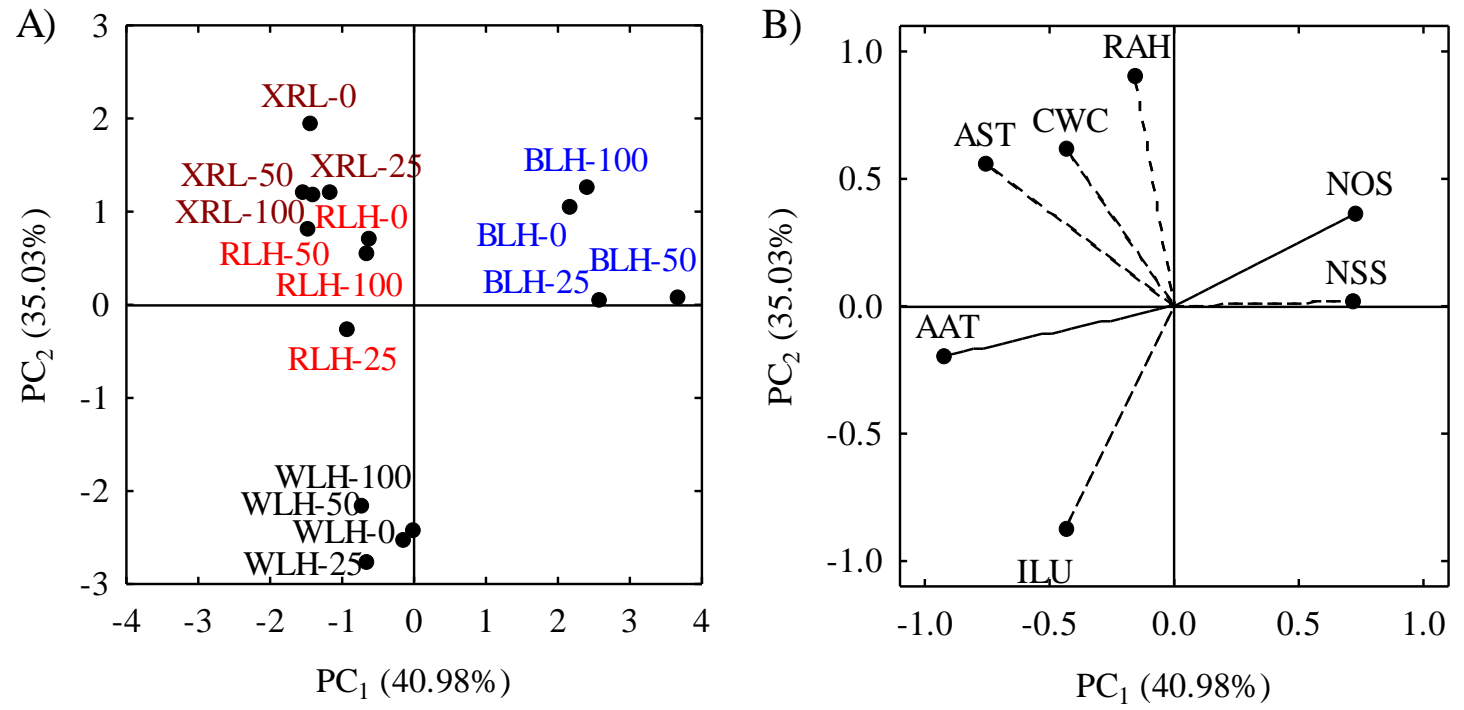

Fig 6. Two-dimensional projection of the interaction among luminosity conditions and Phytohormones concentrations $(\mathrm{A})$ and variables evaluated $(B)$ in the first two main components $\left(\mathrm{MC}_{1}\right.$ and $\left.\mathrm{MC}_{2}\right)$.

Thus, this behavior should have improved the survival of shoots, even without the development of roots, but mostly by the activation of shoot defense systems to adverse microclimatic conditions (Lemoine et al., 2010; Ma et al., 2014).

At 60 DAP no roots formation was observed on $M$. oleifera cuttings because of white (Fig 5A), blue (Fig 5B), red (Fig 5C), and extreme red light conditions (Fig 5D) and phytohormones concentrations. Even with root inducer application, roots formation should be an answer to the light spectrum change. This is verified because plant growth and morphogenesis are influenced by intensity, irradiance, and luminous flux.

It must be observed that photoreceptors, such as phytochromes, cryptochromes, and phototropines absorb specific light spectrum and create signals to modulate gene expression through plant cells signal transduction systems. In fact, light quality has affected phytohormone levels such as auxins, gibberellin, and cytokinin by gene expression associated with metabolic regulation and this may alter secondary metabolites synthesis by photoreceptor signals and lead to reduced plant survival (Fukuda, 2019).

\section{Principle component analysis}

The first two main components (MCs), together accounted for $76.01 \%$ of the total experimental variance. The main first component $\left(\mathrm{MC}_{1}\right)$ accounted for $40.98 \%$ of the total variance and it was formed by the linear combination among the average air temperature (AAT), average soil temperature (AST), number of shoots (NOS), and number of survival shoots (NSS). The second main component $\left(\mathrm{MC}_{2}\right)$ accounted for $35.03 \%$ from remaining variance. It was consisted of combination of cutting water consumption (CWC), air humidity (RAH), and illuminance (ILU).

According to the higher correlation coefficient ( $r$ ) among originals variables and $\mathrm{MCs}$, we found that all variables were important $(r>0.60)$ to explain the influence of light 
spectrum variations and phytohormones concentrations on microclimatic changes, photomorphogenesis and water consumption by $M$. oleifera cuttings. In order of importance, the variables were ranked in the following sequence: RAH > AAT $>$ ILU $>$ AST $>$ NOS $>$ NSS $>$ CWC (Table 2).

Main components analysis (MCA) contributed significantly to reduced original data dimensions into two dimensions (Tran et al., 2019), which facilitate understanding of relationship among the original variables and their contribution to explain the effects of light spectrum variations and phytohormones concentrations on microclimate and $M$. oleifera photomorphogenesis. Alkarkhi and Alqaraghuli (2019) reported that MCA technique allows explaining the total data variation as well as understanding the positive and negative relations among variables.

According to Tripathi and Singal (2019) the reduction of original data dimensions makes the process under study more feasible and economical, because it would drastically reduce time, effort, and cost required to collect data from a large number of variables. This suggests that the reduction of data dimensions and correlation analysis among MCs and these original variables of this current research may contribute for better efficiency and to understand light and phytohormones complexity on climate and $M$. oleififera photomorphogenesis.

We found on $M C_{1}$ that AST and AAT at red and extreme red light decrease NOS and NSS, which were more expressive at blue region. For $\mathrm{MC}_{2}$, we found that ILU increases under white light which promotes RAH and CWC reductions. However, the latter was more expressive when the protected environments were irradiated with extreme red light and without application of phytohormones (Fig 6A and B).

In this study, two dimensions have allowed a better understanding of the relationships among variables and MCs. In Agricultural sciences, the use of MCA will reduce the original dimensions Barbosa et al. (2019). They showed important relationships among the indicator variables of microbiological quality as well as soil enzymatic activity modeling. Ferraz et al. (2018) reported that the relationships between potassium phosphite and foliar nutrients in two dimensions help in decision-making for plants nutritional restoration. This information ratifies the use of this technique to select variables relevant to complex studies.

The results generated in this research are important to guide the adequate protected environments management besides taking into account aspects such as microclimate and irrigation. The efficient use of water resources in semiarid and arid agroecosystems has become increasingly important due to the rapid depletion of water resources. In many cases, evapotranspiration may be the major hydrological cycle component.

It is emphasized that, under stressful environmental conditions, plants accumulate higher concentrations of phytohormones, which leads to a hormonal imbalance and may alter plant growth. Exogenous phytohormone application can also induce greater tolerance to the environmental stresses in the environments protected by the change of light spectrum, modulating the expression of genes involved in plant signaling defenses, transcriptional regulation, hormone biosynthesis, production of reactive oxygen species, and phytohormones metabolism, adapting cuttings shoots to adverse micro-environmental conditions (Podlešáková et al., 2019).
In this context, changes in light quality through the manipulation of light spectrum may be a strategy for the production of quality seedlings in a protected environment, especially in regions with semiarid climate, where the limitation of water resources and the high radiation balance and temperature may limit shoots to growth and development of seedlings propagated by cutting (Fukuda, 2019).

Therefore, application of exogenous phytohormones has gained considerable attention as it will not cause damage to the environment and they are more active under stress conditions, mainly because these are natural substances produced by plants and they act as plant resistance mediators to pathogens and tolerance to abiotic stress conditions (Jini and Joseph, 2019).

\section{Materials and Methods}

\section{Moringa oleifera cuttings}

M. oleifera semi-woody cuttings were collected from 7 am to $9 \mathrm{am}$ of $M$. oleifera mother plants, grown on a rural property located in the city of Lagoa Seca, Paraíba, Brazil, with the following characteristics: $15 \mathrm{~cm}$ in length, 4 to 5 $\mathrm{mm}$ in diameter, and 2 or 3 buds. The cuttings were placed into a polystyrene container on two layers of wet paper towel and transported to the Phytopathology Laboratory of CCAA/UEPB. They were washed in running water and disinfested with $2 \%$ sodium hypochlorite solution for 5 minutes (Paiva et al., 2015). The cuttings were placed into a polystyrene container on two layers of wet paper towel and transported to the Phytopathology Laboratory of CCAA/UEPB. They were washed in running water and disinfested with $2 \%$ sodium hypochlorite solution for 5 minutes (Paiva et al., 2015).

\section{Location and research duration}

The research was carried out between August and November of 2018 at the Phytopathology Laboratory and at a protected environment facility, belonging to the Center of Agricultural and Environmental Sciences (CCAA) of the State University of Paraíba (UEPB), located in Lagoa Seca municipality, in the geographical coordinates Latitude 70 09 'S, Longitude 350 52' W, and altitude $634 \mathrm{~m}$ (Soares et al., 2017). Local climate, according to Köppen's classification, is As' type (tropical humid), with an average annual

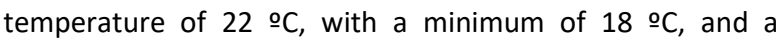
maximum of $33 \stackrel{\circ}{\circ}, 800 \mathrm{~mm}$ rainfall and $80 \%$ relative humidity.

\section{Experimental design}

A completely randomized experimental design with a $4 \times 4$ factorial scheme and three replications was used. The factors consisted of four exogenous phytohormones concentrations (EPET) which were obtained from tiririca (Cyperus rotundus) tubers ( $\mathrm{EPET}_{0}=$ control 0\%; $\mathrm{EPET}_{25}=25 \%$; $\mathrm{EPET}_{50}=50 \%$, and $\mathrm{EPET}_{100}=100 \%$ and four brightness conditions $(\mathrm{WHL}=$ white light; $\mathrm{BLH}=$ blue light; $\mathrm{RLH}=$ red light, and $X R L=$ extreme red light). 


\section{Extraction of exogenous phytohormones}

Tubers of $C$. rotundus plants were obtained from Experimental Field of the CCAA/UEPB where this specie grows naturally. To obtain the aqueous extract of $C$. rotundus, fresh tubers were isolated, washed with water and neutral detergent, dried on paper towel, and weighed. $10 \mathrm{~g}$ of tubers were grinded in a blender with $200 \mathrm{~mL}$ of distilled water, and sieved to obtain a stock solution with $100 \%$ of the tuber extract (Simões et al., 2003).

Phytohormones concentrations for each treatment were obtained by diluting the stock solution with distilled water. $\mathrm{EPET}_{0}=0 \%$ (just distilled water); $\mathrm{EPET}_{25}=25 \%$ (dilution with $75 \%$ distilled water $+25 \%$ stock solution); $\mathrm{EPET}_{50}=50 \%$ (dilution with $50 \%$ distilled water $+50 \%$ stock solution); $\mathrm{EPET}_{100}=100 \%$ (stock solution without water dilution) (Rezende et al., 2013; Scariot et al., 2017).

\section{Light spectrum variation}

To obtain the experimental environment light conditions, four protected environments (mini greenhouses) were built with $2.0 \times 1.0 \times 1.0 \mathrm{~m}$ of length, width, and height, respectively. To obtain the four light conditions, all mini greenhouses were covered with a transparent plastic layer to obtain white light conditions. For blue light, the transparent environment was covered with two layers of blue cellophane paper. For red light, two layers of red cellophane paper were used. For extreme red light we used one layer of red cellophane and one of blue cellophane alternated (Yamashita et al., 2011; Cardoso-Guimarães et al., 2018).

It is also important to point out that the protected environments had their base made by wood boards $(1.0 \mathrm{~m}$ long, $0.10 \mathrm{~m}$ wide, and $0.018 \mathrm{~m}$ thickness). Except for the white light environment, the bases of the other protected environments were covered with black plastic with 200 microns thickness, mainly to avoid the entrance of white light into these environments.

\section{Application of treatments}

Cutting bases were immersed for 10 seconds into solutions corresponding to each concentration of the aqueous extract of $\mathrm{C}$. rotundus, in $0.5 \mathrm{~L}$ containers wrapped and covered with two layers of green cellophane paper, mainly because it is a security light, without influence on phytochromes (Pereira et al., 2011). Afterwards, cuttings were grown in black polyethylene bags with volumetric capacity of $1 \mathrm{dm}^{3}$ and filled up with substrate composed of sandy soil and cattle manure in the ratio of 3:1 and humidity close to the field capacity. The bags with the cuttings were transferred to the four protected environments corresponding to each light condition.

\section{Irrigation management}

Water was applied in a four days irrigation frequency through the weighing method according to Pereira et al. (2005). Evapotranspirated water was replaced within four days prior to each irrigation.

Thus, the weight of polyethylene bags filled with dry substrate (WDS, in $\mathrm{kg}$ ) was obtained. Afterward, the substrate, with initial volume (SIV, in L) corresponding to $75 \%(\mathrm{v} / \mathrm{m})$ of its weight was saturated with water. All bags were placed in polyethylene trays and covered with black plastic to avoid water loss by evaporation. After 24 hours, the drained water volume (DWV, in L) from the bags was collected on the trays and measured. Subsequently, the bags filled with soil at field capacity were weighed (WSF, kg).

From these data, water volume in substrate field capacity (SFC, in L) was calculated by the expression SFC = SIV-DWV. Every four days, the bags were weighed in order to obtain the substrate mass after evapotranspiration (SMET, in $\mathrm{kg}$ ). The mass of evapotranspirated water (WMET, in $\mathrm{kg}$ ) was calculated by the difference WMET = WSF-SMET. Afterwards, the required water volume (RWV, in L) for replacing the soil at field capacity was calculated by the equation RWV $=(\mathrm{SFC} *$ WMET) / WSF. A $300 \mathrm{~mL}$ beaker was used to replace the necessary amount of water. Weights were carried out at night to avoid white light entering into the environments where light conditions were simulated with blue, red, and extreme red lights. For weighing, a portable digital scale, model 123 Util, with 0.00 g precision was used.

\section{Variables evaluated}

The number of shoots was recorded weekly at each experimental unit (NOS). Sixty days after planting (DAP), the number of surviving shoots (NSS) was determined. Afterwards, the cuttings were removed from the polyethylene bags and cleaned out from substrate for root number evaluation (RNE).

Microclimatic variations were monitored inside the protected environments during the experimental period and they were expressed by illuminance variables (ILU, in Ix), average air temperature (AET, in $\left.{ }^{\circ} \mathrm{C}\right)$, average air humidity $\left(\mathrm{AAH}\right.$, in\%), and average soil temperature (AST, in $\left.{ }^{\circ} \mathrm{C}\right)$. Illuminance was measured by a digital luxmeter model LD400 with storage memory of up to 50 readings. Temperature and humidity variables were measured with a digital thermohygrometer with a temperature scale from 0 to $50^{\circ} \mathrm{C}$ and relative humidity from 20 to $99 \%$, with accuracy of \pm 1 。 $C$ temperature and $\pm 5 \%$ relative humidity.

Cuttings evapotranspirated water consumption throughout the experimental period (CEW, in L) were calculated from the sum of necessary water volumes (NWV, in L) to replenish the soil to the field capacity condition at each irrigation frequency, given by the expression "CEW $=\Sigma N W V$ ".

\section{Statistical analyzes}

Data were submitted to Shapiro-Wilk's normality test (Shapiro and Wilk, 1965) and analysis of variance by $F$ test with $95 \%$ confidence. For the unfolding of degrees of freedom of luminosity environment, the Tukey multiple comparisons test at the level of $5 \%$ of probability was applied, whereas for phytohormones concentrations, a polynomial regression analysis was carried out and the selection of mathematical models was determined by the regression parameters significance (Barbosa e Maldonado Júnior, 2015), by software Sisvar 5.6 (Ferreira, 2014).

To establish the most important variables and to explain the observed effects, the data were standardized to make the mean zero $(X=0.0)$ and the unit variance $(\sigma 2=1.0)$. The Exploratory Analysis of Main Components (EMC) was carried out and the amount of relevant information was condensed in a smaller number of dimensions, which resulted from the linear combinations of the original variables generated from 
the highest eigenvalues $(\lambda>1.0)$ in the covariance matrix, explaining a percentage greater than $10 \%$ of the total variance (Govaerts et al., 2007; Hair et al., 2009).

\section{Conclusion}

Illuminance was reduced in environments under blue, red, and extreme red light. Air temperature was decreased under blue light, while the red and extreme red lights increased temperature and relative humidity, soil temperature, and water consumption by the cuttings.

Protected environments and illuminated with blue light and the application of phytohormones enabled the emergence of shoots and survival of $M$. oleifera cuttings, even without the formation of roots after 60 days of planting and the variability of the microclimatic conditions.

All variables included in this study were considered important to explain the influence of variation of light spectrum and phytohormones concentrations on environmental microclimate changes, photomorphogenesis, and water consumption by $M$. oleifera cuttings.

\section{Acknowledgment}

The authors would like to thank the Paraíba State University (UEPB), Group of Agricultural Sciences Studies in Semi-Arid (GECAS), National Council for Scientific and Technological Development $(\mathrm{CNPq})$, and the Coordination for the Improvement of Higher Personnel Education (CAPES).

\section{References}

Aekthammarat A, Pannangpetch P, Tangsucharit P (2019) Moringa oleifera leaf extract lowers high blood pressure by alleviating vascular dysfunction and decreasing oxidative stress in L-NAME hypertensive rats. Phytomed. 54:9-16.

Aguilar-Camacho M, Welti-Chanes J, Jacobo-Velázquez (2019) Combined effect of ultrasound treatment and exogenous phytohormones on the accumulation of bioactive compounds in broccoli florets. Ultrason Sonochem. 50:289-301.

Alkarkhi AFM, Alqaraghuli WAA (2019) Principal Components Analysis. In: Alkarkhi AFM, Alqaraghuli WAA (eds) Easy Statistics for Food Science with R, Academic Press, Amsterdã.

Azzurra A, Massimiliano A, Angela M (2019) Measuring sustainable food consumption: A case study on organic food. Sust Prod Cons. 17:95-107.

Barbosa JC, Maldonado Júnior W (2015) Experimentação Agronômica \& AgroEstat - Sistema para Análises Estatísticas de Ensaios Agronômicos. Funep, Jaboticabal, São Paulo, p 396.

Barbosa MA, Ferraz RLS, Coutinho ELM, Coutinho Neto AM, Silva MS, Fernandes C, Rigobelo EC (2019) Multivariate analysis and modeling of soil quality indicators in longterm management systems. Sci Total Environ. 657(3):457465.

Cardoso-Guimarães CAF, Nascimento EA, Luna CLA, Ferraz RLS, Costa PS, Araújo MA (2018) Germinação e crescimento inicial de Moringa oleifera sob variação do espectro luminoso e fitormônios. Trabalho apresentado no IV Encontro de Extensão, Pesquisa e Inovação em Agroecologia, Instituto Federal da Paraíba, Picuí, 4-6 dezembro 2018.
Cavalcante JA, Lopes KP, Pereira NAE, Silva JG, Pinheiro RM, Marques RLL (2018) Extrato aquoso de bulbos de tiririca sobre a germinação e crescimento inicial de plântulas de rabanete. Rev Ver Agroec Des Sust. 13(1):39-44.

Domenico M, Lina C, Francesca B (2019) Sustainable Crops for Food Security: Moringa (Moringa oleifera Lam.). Ency Food Sec Sust. 1:409-415.

Fernandes ALT, Fraga Júnior EF, Takay BY (2011) Avaliação do método Penman-Piche para a estimativa da evapotranspiração de referência em Uberaba, MG. Rev Bras Eng Agric Ambient. 15(3):270-276.

Ferraz RLS, Barbosa MA, Wanderley MJA, Costa PS, Magalhães ID, Medeiros AS, Faria HM, Marchioro V, Melo AS, Anjos FA (2018) Potassium phosphite reduction of Candidatus Liberibacter spp. population on leaves of 'Ponkan' tangerines tree with huanglongbing. Afr J Microbiol Res. 12(10):248-253.

Ferreira DF (2014) Sisvar: a Guide for its Bootstrap procedures in multiple comparisons. Ciênc Agrotec. 38(2):109-112.

Fukuda N (2019) Plant growth and physiological responses to light conditions author links open overlay panel. In: Anpo M, Fukuda $\mathrm{H}$, Wada T (eds) Plant Factory Using Artificial Light: Adapting to Environmental Disruption and Clues to Agricultural Innovation, Elsevier, Amsterdã.

Gao H, Yan C, Liu Q, Ding W, Chen B, Li Z (2019) Effects of plastic mulching and plastic residue on agricultural production: A meta-analysis. Sci Total Environ. 651:484492.

González CV, Jeréz DM, Jofré MF, Guevara A, Prieto J, Mazza C, Williams LE, Giordano CV (2019) Blue light attenuation mediates morphological and architectural acclimation of Vitis vinifera cv. Malbec to shade and increases light capture. Environ Exp Bot. 157:112-120.

Govaerts B, Sayre KD, Lichter K, Dendooven L, Deckers J (2007) Influence of permanent raised bed planting and residue management on physical and chemical soil quality in rain fed maize/wheat systems. Plant Soil. 291:39-54.

Hair FJ, Black WC, Babin BJ, Anderson RE Tatham RL (2009) Análise Multivariada de Dados. Tradução Adonai Schlup Sant'Anna. 6th edn. Bookman, Porto Alegre.

Jeong SW, Hogewoning SW, leperen W (2014) Responses of supplemental blue light on flowering and stem extension growth of cut chrysanthemum. Sci Hortic. 165:69-74.

Jini D, Joseph B (2019) Use of phytohormones in improving abiotic stress tolerance to rice. In: Hasanuzzaman M, Fujita M, Nahar K, Biswas JK (eds) Advances in Rice Research for Abiotic Stress Tolerance, Woodhead Publishing, Amsterdã.

Kong Y, Schiestel K, Zheng Y (2019) Pure blue light effects on growth and morphology are slightly changed by adding low-level UVA or far-red light: A comparison with red light in four microgreen species. Environ Exp Bot. 157:58-68.

Lemoine ML, Chaves AR, Martínez GA (2010) Influence of combined hot air and UV-C treatment on the antioxidant system of minimally processed broccoli (Brassica oleracea L var. Italica). LWT - Food Sci Technol. 43:1313-1319.

Lemos Filho LCA, Carvalho LG, Evangelista AWP, Alves Júnior J (2010) Análise espacial da influência dos elementos meteorológicos sobre a evapotranspiração de referência em Minas Gerais. Rev Bras Eng Agric Ambient. 14(12):1294-1303.

Lin $\mathrm{KH}$, Huang MY, Huang WD, Hsu MH, Yang ZW, Yang CM (2013) The effects of red, blue, and white light-emitting diodes on the growth, development, and edible quality of 
hydroponically grown lettuce (Lactuca sativa L. var. capitata). Sci Hortic. 150:86-91.

Long J, Yuan X, Ma C, Du M, Ma X, Wen Z, Ma R, Wanga Y, Cao $Y$ (2018) Strongly enhanced luminescence of $\mathrm{Sr}_{4} \mathrm{Al}_{14} \mathrm{O}_{25}: \mathrm{Mn}^{4+}$ phosphor by co-doping $\mathrm{B}^{3+}$ and $\mathrm{Na}^{+}$ions with red emission for plant growth LEDs. Royal Soci Chem Advanc. 3.

Ma G, Zhang L, Setiawan CK, Yamawaki K, Asai T, Nishikawa F, Maezawa S, Sato H, Kanemitsu N, Kato M (2014) Effect of red and blue LED light irradiation on ascorbate content and expression of genes related to ascorbate metabolism in postharvest broccoli. Postharvest Biol Technol. 94:97103.

Maciel SPA, Zanella F, Lima ALS (2007) Efeito do sombreamento sobre a produção de alface em hidroponia. Rev Ciên Consci. 2(1).

Mutti PR, Silva LL, Medeiros SS, Dubreuil V, Mendes KR, Marques TV, Lúcio OS, Silva CMS, Bezerra BG (2019) Basin scale rainfall-evapotranspiration dynamics in a tropical semiarid environment during dry and wet years. Int J Appl Earth Obs Geoinf. 75:29-43.

Oka Y, Yamamoto K (2019) Photoreceptor-Mediated Plant Development. In: Anpo M, Fukuda H, Wada T (eds) Plant Factory Using Artificial Light: Adapting to Environmental Disruption and Clues to Agricultural Innovation, Elsevier, Amsterdã.

Paiva EP, Rocha RHC, Praxedes SC, Guedes WA, Sá FVS (2015) Crescimento e qualidade de mudas de romãzeira 'wonderful' propagadas por estaquia. Rev Caatinga. 28(2):64-75.

Parajuli K, Jones SB, Tarboton DG, Flerchinger GN, Hipps LE, Allen LN, Seyfried MS (2019) Estimating actual evapotranspiration from stony-soils in montane ecosystems. Agric For Meteorol. 265:183-194.

Páramo-Calderón DE, Aparicio-Saguilán A, Aguirre-Cruz A, Carrillo-Ahumada J, Hernández-Uribe JP, Acevedo-Tello $S$, Torruco-Uco JG (2019) Tortilla added with Moringa oleifera flour: Physicochemical, texture properties and antioxidant capacity. LWT. 100:409-415.

Pereira JRD, Carvalho JA, Miguel DS, Santana MJ (2005) Consumo de água pela cultura do crisântemo cultivada em ambiente protegido. Eng Agríc. 25(3):651-659.

Pereira MC, Cardoso NP, Giancotti PRF, Alves PLAC (2011) Germinação de sementes de melão-de-são-caetano sob variação de água, luz e temperatura. Biosci J. 279(3):363370.

Pivetta CR, Heldwein AB, Maldaner IC, Radons SR, Tazzo IF, Lucas DD (2010) Evapotranspiração máxima do pimentão cultivado em estufa plástica em função de variáveis fenométricas e meteorológicas. Rev Bras Eng Agric Ambient. 14:768-775.

Podlešáková K, Ugena L, Spíchal L, Doležal K, Diego N (2019) Phytohormones and polyamines regulate plant stress responses by altering GABA pathway. New Biotechnol. 48:53-65.

Pokorny J (2019) Evapotranspiration. In: Fath B (ed) Encyclopedia of Ecology. Elsevier, Amsterdã.

Purquerio LFV, Tivelli SW (2006) Manejo do ambiente em cultivo protegido. Informações Tecnológicas, Campinas. IAC. Available

at:

http://www.iac.sp.gov.br/Tecnologias/MANEJO_Cultivo_P rotegido/Manejo_Cultivo_protegido.htm [Accessed Dec. 01, 2018].
Rezende FPF, Zuffellato-Ribas KC, Koehler HS (2013) Aplicação de extratos de folhas e tubérbulos de Cyperus rotundus $\mathrm{L}$. e de auxinas sintéticas na estaquia caulinar de Duranta repens L. Rev Bras Plantas Med. 15(4):639-645.

Santos LL, Seabra Junior S, Nunes MCM (2010) Luminosidade, temperatura do ar e do solo em ambientes de cultivo protegido. Rev Ciênc Agro-Ambient. 8(1):83-93.

Scariot E, Bonome LTS, Bittencourt HVH, Lima CSM (2017) Extrato aquoso de Cyperus rotundus no enraizamento de estacas lenhosas de Prunus persica cv. 'Chimarrita'. Rev Ciênc Agrovet. 16(2):195-200.

Shapiro SS, Wilk MB (1965) An Analysis of Variance Test for Normality (Complete Samples). Biometrika Trust. 52(3/4):591-611.

Simões CMO, Schenkel EP, Gosmann G, Mello JCP, Mentz LA, Petrovick PR (2003) Farmacognosia: da planta ao medicamento. 5th edn. Ed. da UFSC, Florianópolis.

Soares CS, Silva JA, Silva GN (2017) Produção de coentro em diferentes espaçamentos dos canais hidropônicos. Pesq Agropec Pernambuc. 22:1-5.

Tran NM, Burdejová P, Ospienko M, Härdle WK (2019) Principal component analysis in an asymmetric norm. J Multivar Anal. 171:1-21.

Tripathi M, Singal SK (2019) Use of Principal Component Analysis for parameter selection for development of a novel Water Quality Index: A case study of river Ganga India. Ecol Indic. 96:430-436.

Valenga MGP, Boschen NL, Rodrigues PRP, Maia GAR (2019) Agro-industrial waste and Moringa oleifera leaves as antioxidants for biodiesel. Ind Crop Prod. 128:331-337.

Virk AK, Kumari C, Tripathi A, Kakade A, Li X, Kulshrestha S (2019) Development and efficacy analysis of a Moringa oleifera based potable water purification kit. J Water Proc Engin. 27:37-46.

Xu HL, Xu QC, Li FL, Feng YZ, Qin FF, Fang W (2012) Applications of xerophytophysiology in plant productionLED blue light as a stimulus improved the tomato crop. Sci Hortic. 148:190-196.

Yamashita OM, Guimaraes SC, Cavenaghi AL (2011) Germinação das sementes de Conyza canadensis e Conyza bonariensis em função da qualidade de luz. Planta Daninha. 29(4):737-743.

Yang C, Xie F, Jiang Y, Li Z, Huang X, Li L (2018) Phytochrome a negatively regulates the shade avoidance response by increasing auxin/indole acidic acid protein stability. Dev Cell. 44(1):29-41.

Zhang Q, Yu H, Sun P, Singh VP, Shi P (2019a) Multisource data based agricultural drought monitoring and agricultural loss in China. Glob Planet Change. 172:298306.

Zhang $\mathrm{T}$, Jeong $\mathrm{CH}$, Cheng WN, Bae H, Seo HG, Petriello MC, Han SG (2019b) Moringa extract enhances the fermentative, textural, and bioactive properties of yogurt. LWT. 101:276-284. 